\title{
Pengembangan Potensi Energi Alternatif Dengan Pemanfaatan Limbah Cair Kelapa Sawit Sebagai Sumber Energi Baru Terbarukan Di Kabupaten Kotawaringin Timur
}

\author{
Yulian Mara Alkusma1 ${ }^{1}$ Hermawan ${ }^{1,2}$, Hadiyanto ${ }^{1,3}$ \\ ${ }^{1}$ Magister Ilmu Lingkungan Universtias Diponegoro \\ 2Departemen Teknik Elektro Fakultas Teknik Universitas Diponegoro \\ ${ }^{3}$ Departemen Teknik Kima Fakultas Teknik Universitas Diponegoro
}

\begin{abstract}
ABSTRAK
Energi memiliki peranan penting dalam proses pembangunan yang pada akhirnya untuk mencapai tujuan sosial, ekonomi dan lingkungan untuk serta merupakan pendukung bagi kegiatan ekonomi nasional. Sumber energi terbarukan yang berasal dari pemanfaatan biogas limbah cair kelapa sawit dapat menghasilkan energi listrik yang saat ini banyak bergantung pada generator diesel dengan biaya yang mahal.Limbah cair kelapa sawit (Palm Oil Mill Effluent atau POME) adalah limbah cair yang berminyak dan tidak beracun, berasal dari proses pengolahan minyak kelapa sawit, namun limbah cair tersebut dapat menyebabkan bencana lingkungan apabila tidak dimanfaatkan dan dibuang di kolam terbuka karena akan melepaskan sejumlah besar gas metana dan gas berbahaya lainnya ke udara yang menyebabkan terjadinya emisi gas rumah kaca. Tingginya kandungan Chemical Oxygen Demand (COD) sebesar 50.000-70.000 mg/l dalam limbah cair kelapa sawit memberikan potensi untuk dapat di konversi menjadi listrik dengan menangkap biogas (gas metana) yang dihasilkan melalui serangkaian tahapan proses pemurnian. Di Kabupaten Kotawaringin Timur terdapat 36 Pabrik Pengolahan Kelapa Sawit yang total kapasitas pabriknya adalah sebesar 2.115 TBS/jam, menghasilkan limbah cair sebesar 1.269 ton limbah cari/jam dan mampu menghasilkan $42.300 \mathrm{~m} 3$ biogas.
\end{abstract}

Kata kunci: Renewable Energy, Plam Oil Mill Effluent, Chemical Oxygen Demand, Biogass, Methane.

\begin{abstract}
Energy has an important role in the development process and ultimately to achieve the objectives of social, economic and environment for as well as an environmental support for national economic activity. Renewable energy source derived from wastewater biogas utilization of oil palm can produce electrical energy which is currently heavily dependent on diesel generators at a cost that mahal.Limbah liquid palm oil (Palm Oil Mill Effluent, or POME) is the wastewater that is greasy and non-toxic, derived from the processing of palm oil, but the liquid waste could cause environmental disaster if not used and disposed of in open ponds because it will release large amounts of methane and other harmful gases into the air that cause greenhouse gas emissions. The high content of Chemical Oxygen Demand (COD) of 50000-70000 mg / l in the liquid waste palm oil provides the potential to be converted into electricity by capturing the biogas (methane gas) produced through a series of stages of the purification process. In East Kotawaringin there are 36 palm oil processing factory that total factory capacity is of 2,115 TBS / hour, producing 1,269 tons of liquid waste wastewater / $\mathrm{h}$ and is capable of producing 42,300 $\mathrm{m} 3$ of biogas.
\end{abstract}

Keywords: Renewable Energy, Plam Oil Mill Effluent, Chemical Oxygen Demand, Biogass, Methane

Cara sitasi: Alkusma, Y.M., Hermawan, dan Hadiyanto. (2016). Pengembangan Potensi Energi Alternatif dengan Pemanfaatan Limbah Cair Kelapa Sawit sebagai Sumber Energi Baru Terbarukan di Kabupaten Kotawaringin Timur. Jurnal Ilmu Lingkungan,14(2),96-102, doi:10.14710/jil.14.2.96-102

\section{PENDAHULUAN}

Hutan bakau atau disebut juga hutan mangrove adalah hutan yang tumbuh di rawa-rawa berair payau yang terletak pada garis pantai dan dipengaruhi oleh pasang surut air laut. Hutan mangrove ini bertumbuh pesat memenuhi tempat dimana terjadi pelumpuran dan akumulasi bahan organik. Baik di daerah yang terlindung dari gempuran ombak, maupun di sekitar muara sungai dimana arus laut lemah dan mengendapkan lumpur yang dibawa dari hulu sungai.
Energi mempunyai peranan penting dalam pencapaian tujuan sosial, ekonomi dan lingkungan untuk pembangunan berkelanjutan serta merupakan pendukung bagi kegiatan ekonomi nasional. Penggunaan energi di Indonesia meningkat pesat sejalan dengan pertumbuhan ekonomi dan pertambahan penduduk. Sedangkan akses ke energi yang andal dan terjangkau merupakan prasyarat utama untuk meningkatkan standar hidup masyarakat. 
Alkusma, Y.M., Hermawan, dan Hadiyanto. (2016). Pengembangan Potensi Energi Alternatif dengan Pemanfaatan Limbah Cair Kelapa Sawit sebagai Sumber Energi Baru Terbarukan di Kabupaten Kotawaringin Timur. Jurnal Ilmu Lingkungan,14(2),96-102, doi:10.14710/jil.14.2.96-102

Keterbatasan akses ke energi komersial telah menyebabkan pemakaian energi per kapita masih rendah dibandingkan dengan negara lainnya. Konsumsi per kapita pada saat ini sekitar 3 SBM yang setara dengan kurang lebih sepertiga konsumsi per kapita rata-rata negara ASEAN. Dua pertiga dari total kebutuhan energi nasional berasal dari energi komersial dan sisanya berasal dari biomassa yang digunakan secara tradisional (non-komersial). Sekitar separuh dari keseluruhan rumah tangga belum terjangkau dengan sistem elektrifikasi Nasional.

Penggunaan BBM meningkat pesat, terutama untuk transportasi, yang sulit digantikan oleh jenis energi lainnya. Ketergantungan kepada BBM masih tinggi, lebih dari 60 persen dari konsumsi energi final. Pembangkitan tenaga listrik di beberapa lokasi tertentu masih mengandalkan BBM karena pada waktu yang lalu harga BBM masih relatif murah (karena di subsidi), jauh dari sumber batubara, jaringan pipa gas bumi masih terbatas, lokasi potensi tenaga air yang jauh dari konsumen dan pengembangan panas bumi serta energi terbarukan lain yang relatif masih lebih mahal.

Kebutuhan energi dalam negeri selama ini dipasok dari produksi dalam negeri dan sebagian dari impor, yang pangsanya cenderung meningkat. Komponen terbesar dari impor energi adalah minyak bumi dan BBM. Kemampuan produksi lapangan minyak bumi semakin menurun sehingga membatasi tingkat produksinya. Dalam satu dekade terakhir, kapasitas produksi kilang BBM dalam negeri tidak bertambah, sedangkan permintaan BBM di dalam negeri meningkat dengan cepat. Pada tahun 2005 peranan minyak bumi impor untuk kebutuhan bahan baku kilang BBM sudah mencapai 40 persen sedangkan peranan BBM impor untuk pemakaian dalam negeri mencapai 32 persen.

Mengapa energi terbarukan? Energi Terbarukan harus segera dikembangkan secara nasional bila tetap tergantungan energi fosil, ini akan menimbulkan setidaknya tiga ancaman serius yakni:

1) Menipisnya cadangan minyak bumi yang diketahui (bila tanpa temuan sumur minyak baru)

2) Kenaikan/ketidakstabilan harga akibat laju permintaan yang lebih besar dari produksi minyak, dan

3) Polusi gas rumah kaca (terutama CO) akibat pembakaran bahan bakar fosil.

Kadar CO saat ini disebut sebagai yang tertinggi selama 125 tahun belakangan [2]. Bila ilmuwan masih memperdebatkan besarnya cadangan minyak yang masih bisa dieksplorasi, efek buruk CO terhadap pemanasan global telah disepakati hampir oleh semua kalangan. Hal ini menimbulkan ancaman serius bagi kehidupan makhluk hidup di muka bumi. Oleh karena itu, pengembangan dan implementasi bahan bakar terbarukan yang ramah lingkungan perlu mendapatkan perhatian serius

Perkembangan bisnis dan investasi kelapa sawit dalam beberapa tahun terakhir mengalami pertumbuhan yang sangat pesat. Permintaan atas minyak nabati dan penyediaan biofuel telah mendorong peningkatan permintaan minyak nabati yang bersumber dari crude palm oil (CPO) yang berasal dari kelapa sawit. Hal ini disebabkan tanaman kelapa sawit memiliki potensi menghasilkan minyak sekitar 7 ton/hektar lebih tinggi dibandingkan dengan kedelai yang hanya 3 ton/hektar. Indonesia memiliki potensi yang sangat besar dalam pengembangan perkebunan dan industri kelapa sawit karena memiliki potensi cadangan lahan yang cukup luas, ketersediaan tenaga kerja, dan kesesuaian agroklimat. Luas perkebunan kelapa sawit pada tahun 2007 sekitar 6,8 juta hektar (Heriyadi, 2009). Dari luas tersebut sekitar $60 \%$ diusahakan oleh perkebunan besar dan sisanya diusahakan oleh perkebunan rakyat (Soetrisno, 2008).

Kabupaten Kotawaringin Timur memiliki potensi perkebunan dengan jumlah perusahaan perkebunan besar swasta hampir 60 perusahaan besar swasta dan hampir $50 \%$ dari jumlah tersebut telah memiliki pabrik pengolahan kelapa sawit. Pada kenyataannya limbah kelapa sawit yang ada masih belum dapat dimanfaatkan secara optimal, diantaranya sebagai sumber pembangkit energi alternatif, terutama sebagai sumber energi alternatif bagi daerah-daerah perdesaan yang belum terjangkau jaringan listrik yang dikelola oleh pemerintah (PLN) selama ini. Tulisan ini merupakan gagasan dari melimpahnya limbah cair yang ada di Kabupaten Kotawarngin Timur yang belum di maksimalkan penggunaannya berkaitan dengan kemandirian energi dari sumber energi baru terbarukan.

\section{Perkebunan Kelapa Sawit dan Biogas}

Salah satu potensi perkebunan yang cukup besar didapatkan dari Pabrik Kelapa Sawit (PKS), yang mengolah Tandan Buah Segar (TBS) Kelapa Sawit menjadi Crude Palm Oil (CPO). Dalam proses pengolahannya, PKS menghasilkan limbah biomassa dengan jumlah yang cukup besar dalam bentuk limbah organik berupa tandan kosong kelapa sawit (Tankos), cangkang dan sabut, serta limbah cair (palm oil mill effluent/POME).

Seperti peta konversi di atas, pada umumnya cangkang dan sabut dikonversi menjadi energi panas dengan dibakar di dalam boiler untuk menghasilkan uap (steam) bertekanan. Uap tersebut selanjutnya dikonversi kembali menjadi energi listrik melalui turbin generator dan sisanya digunakan untuk proses pengolahan kelapa sawit. Limbah biomassa yang lain, yaitu tankos dan POME sebenarnya juga memiliki potensi energi yang tinggi, namun pada umumnya belum dimanfaatkan secara optimal. POME diurai di kolam limbah sedangkan tankos biasanya disebarkan ke lahan dan dibiarkan membusuk secara alami. Proses pembusukan biomassa ini akan menghasilkan biogas dengan kandungan utama (62\%) gas methana $\left(\mathrm{CH}_{4}\right)$. Gas ini muncul sebagai akibat dari proses perombakan senyawa-senyawa organik secara anaerobik. 
Gas methana tersebut ternyata juga memiliki tingkat emisi yang tinggi. UNFCCC, badan PBB yang menangani perubahan iklim, mencatat gas methana memiliki tingkat emisi 24 kali jika dibandingkan dengan gas karbon $\left(\mathrm{CO}_{2}\right)$. Di sisi lain, gas methana ini juga memiliki tingkat energi yang cukup tinggi. Gas methana ini memiliki nilai kalor 50,1 MJ/kg. Jika densitas methana $0,717 \mathrm{~kg} / \mathrm{m}^{3}$ maka $1 \mathrm{~m}^{3}$ gas methana akan memiliki energi setara dengan 35,9 MJ atau sekitar $10 \mathrm{kWh}$. Jika kandungan gas methana adalah $62 \%$ dalam biogas, maka $1 \mathrm{~m}^{3}$ biogas akan memiliki tingkat energi sebesar 6,2 kWh. Melihat potensi tersebut sangat disayangkan jika gas-gas yang dihasilkan dari penguraian biomassa tersebut dibiarkan begitu saja. Untuk dapat memanfaatkan potensi biogas tersebut, terdapat beberapa teknologi yang dapat diterapkan.

\section{Palm Oil Mill Effluent (POME)}

Teknologi yang telah banyak digunakan untuk mengambil biogas dari POME adalah Covered Lagoon. Teknologi ini dilakukan dengan menutup kolam limbah konvensional dengan bahan reinforced polypropylene sehingga berfungsi sebagai anaerobic digester. Biogas akan tertangkap dan terkumpul di dalam cover.

Dengan teknologi ini, akan dihasilkan biogas sebanyak $\pm 20 \mathrm{~m}^{3} /$ ton TBS. Jadi jika kapasitas PKS sebesar 30 ton TBS/jam akan menghasilkan biogas $\pm 600 \mathrm{~m}^{3} / \mathrm{jam}$, atau setara dengan energi sebesar $3.720 \mathrm{kWh}$. Jika energi tersebut digunakan untuk membangkitkan listrik dengan menggunakan gas engine (efisiensi 35\%) maka akan dapat dibangkitkan listrik sebesar $1.303 \mathrm{kWh}$ atau 1,3 MW.

Jika dihitung secara ekonomi, dengan asumsi pembangkit beroperasi selama 300 hari/tahun dan 24 jam/hari dan harga ditetapkan Rp. 975/kWh, sesuai permen ESDM (04/2012) untuk pulau Jawa, maka terdapat potensi pendapatan sebesar Rp. 9,15 $\mathrm{M} /$ tahun.

Teknologi yang berbeda adalah dengan menggunakan anaerobic digester. Teknologi ini lebih efektif baik dalam pengolahan limbah POME sehingga akan dihasilkan biogas dalam jumlah yang lebih besar. Pengolahan POME dilakukan dengan membuat instalasi anaerobic digester seperti yang terlihat pada skema gambar 4. Komponen utama teknologi ini adalah sebuah reaktor yang senantiasa terkontrol. Dengan demikian proses penguraian senyawa organik secara anaerobic dapat diatur, baik komposisi, mikrobia maupun termperaturnya untuk mendapatkan hasil yang maksimal dengan tingkat BOD yang lebih rendah dari $100 \mathrm{mg} / \mathrm{l}$.

Biogas yang dihasilkan $\pm 28 \mathrm{~m} 3 /$ ton TBS. Jadi jika kapasitas PKS sebesar 30 ton TBS/jam akan dihasilkan biogas $\pm 840 \mathrm{~m}^{3} / \mathrm{jam}$, atau setara dengan energi sebesar $5.208 \mathrm{kWh}$. Energi listrik yang dapat dibangkitkan dengan gas engine (efisiensi 35\%) adalah sebesar $1.822 \mathrm{kWh}$, atau 1,8 MW. Dengan asumsi yang sama, maka potensi pendapatan adalah sebesar Rp. 12,8 M/tahun.

98
Dengan potensi yang cukup besar tersebut diharapkan sektor perkebunan mulai tertarik untuk berkontribusi dalam kemandirian energi. Maka menjadi penting bahwa sektor energi menjadi salah satu aksi korporasi yang cukup strategis untuk diterapkan di industri perkebunan Indonesia.

\section{Operasional Unit Pemanfaatan Biogas}

Metode pengolahan limbah dapat dilakukan secara fisika, kimia, dan biologi. Pengolahan limbah secara kimia dilakukan dengan proses koagulasi, flokulasi, sedimentasi, dan flotasi. Proses kimia sering kurang efektif karena pembelian bahan kimianya yang cukup tinggi dan menghasilkan sludge dengan volume yang cukup besar. Sedangkan pengolahan limbah secara biologis dapat dilakukan dengan proses aerob dan anaerob.

Secara konvensional pengolahan limbah cair PMKS dilakukan secara biologis dengan menggunakan kolam, yaitu limbah cair diproses dalam kolam aerobik dan anaerobik dengan memanfaatkan mikrobia sebagai perombak BOD dan menetralisir keasaman cairan limbah.

Pengolahan limbah cair PMKS secara konvesional banyak dilakukan oleh pabrik karena teknik tersebut cukup sederhana dan biayanya lebih murah. Namun pengolahan dengan cara tersebut membutuhkan lahan yang luas untuk pengolahan limbah. Dengan kapasitas 30 ton TBS/jam, maka dibutuhkan sekitar 7 hektar lahan untuk pengolahan limbah. Selain itu efisiensi perombakan limbah cair PMKS hanya 60-70 \% dengan waktu retensi yang cukup lama yaitu 120-140 hari. Kolam-kolam limbah konvensional akan mengeluarkan gas methan (CH4) dan karbon dioksida (CO2) yang membahayakan karena merupakan emisi penyebab efek rumah kaca yang berbahaya bagi lingkungan. Disamping itu kolam-kolam pengolahan limbah sering mengalami pendangkalan, sehingga baku mutu limbah tidak tercapai.

Pengolahan limbah cair PMKS dengan menggunakan digester anaerob dilakukan dengan mensubtitusi proses yang terjadi di kolam anaerobik pada sistem konvensional kedalam tangki digester. Tangki digester berfungsi menggantikan kolam anaerobik yang dibantu dengan pemakaian bakteri mesophilic dan thermophilic (Naibaho, 1996). Kedua bakteri ini termasuk bakteri methanogen yang merubah substrat dan menghasilkan gas methan.

Fermentasi anaerobik dalam proses perombakan bahan organik yang dilakukan oleh sekelompok mikrobia anaerobik fakultatif maupun obligat dalam satu tangki digester (reaktor tertutup) pada suhu 35-55 0C. Metabolisme anaerobik selulose melibatkan banyak reaksi kompleks dan prosesnya lebih sulit daripada reaksi-reaksi anaerobik bahanbahan organik lain seperti karbohidrat, protein, dan lemak. Bidegradasi tersebut melalui beberapa tahapan yaitu proses hidrolisis, proses asidogenesis, proses asetogenesis, dan proses methanogenesis. Proses hidrolisis berupa proses dekomposisi 
Alkusma, Y.M., Hermawan, dan Hadiyanto. (2016). Pengembangan Potensi Energi Alternatif dengan Pemanfaatan Limbah Cair Kelapa Sawit sebagai Sumber Energi Baru Terbarukan di Kabupaten Kotawaringin Timur. Jurnal Ilmu Lingkungan,14(2),96-102, doi:10.14710/jil.14.2.96-102

biomassa kompleks menjadi gkukosa sederhana memakia enzim yang dihasilkan oleh mikroorganisme sebagai katalis. Hasilnya biomassa menjadi dapat larut dalam air dan mempunyai bentuk yang lebih sederhana. Proses asidogenesis merupakan proses perombakan monomer dan oligomer menjadi asam asetat, CO2, dan asam lemak rantai pendek, serta alkohol. Proses asidogenesis atau fase non methanogenesis menghasilkan asam asetat, CO2, dan H2. Sementara proses methanogensesis merupakan perubahan senyawa-senyawa menjadi gas methan yang dilakukan oleh bakteri methanogenik. Salah satu bakteri methanogeneik yang populer dalam Methanobachillus omelianskii.

Proses biokonversi methanogenik merupakan proses biologis yang sangat dipengaruhi oleh faktor lingkungan baik lingkungan biotik maupun abiotik. Faktor biotik meliputi mikroba dan jasad aktif. Faktor jenis dan konsentrasi inokulum sangat berperan dalam proses perombakan dan produksi biogas. Hasil penelitian Mahajoeno, dkk (2008) mengungkapkan inokulum LKLM II-20\% (b/v) dengan substrat 15 L, diperoleh produksi biogas paling baik dibandingkan konsentrasi lainnya dimana produksi biogasnya mencapai 121 liter.

Sedangkan faktor abiotik meliputi pengadukan (agitasi), suhu, tingkat keasaman ( $\mathrm{pH}$ ), kadar substrat, kadar air, rasio $\mathrm{C} / \mathrm{N}$, dan kadar $\mathrm{P}$ dalam substrat, serta kehadiran bahan toksik (Mahajoeno, dkk, 2008). Diantara faktor abiotik di atas, faktor pengendali utama produksi biogas adalah suhu, $\mathrm{pH}$, dan senyawa beracun.

Kehidupan mikroba dalam cairan memerlukan keadaan lingkungan yang cocok antara lain $\mathrm{pH}$, suhu, dan nutrisi. Derajat keasaman pada mikroba yaitu antara pH 5-9. Oleh karena itu limbah cair PMKS yang bersifat asam (pH 4-5) merupakan media yang tidak cocok untuk pertumbuhan bakteri, maka untuk mengaktifkan bakteri cairan limbah PMKS tersebut harus di netralisasi. Penambahan bahan penetral $\mathrm{pH}$ dapat meningkatkan produksi biogas. Namun keasaman nya dibatasi agar tidak melebihi pH 9, karena pada pH 5 dan pH 9 dapat menyebabkan terganggunya enzim bakteri (enzim teridir dari protein yang dapat mengkoagulasi pada $\mathrm{pH}$ tertentu). Peningkatan $\mathrm{pH}$ optimum akan memacu proses pembusukan sehingga meningkatkan efektifitas bakteri methanogenik dan dapat meningkatkan produksi biogas. Mahajoeno, dkk (2008) menyatakan menunjukkan bahwa pH substrat awal 7 memberikan peningkatan laju produksi biogas lebih baik dibandingkan dengan perlakuan $\mathrm{pH}$ yang lain

Peningkatan suhu juga dapat meningkatkan laju produksi biogas. Mikroba menghendaki suhu cairan sesuai dengan jenis mikroba yang dikembangkan. Berdasarkan sifat adaptasi bakteri terhadap suhu dapat dibedakan menjadi 3 (tiga) bagian (Naibaho, 1996) yaitu :

- Phsycrophill, yaitu bakteri yang dapat hidup aktif pada suhu rendah yaitu $10{ }^{\circ} \mathrm{C}$, bakteri ini ditemukan pada daerah-daerah sub tropis.
- Mesophill, yaitu bakteri yang hidup pada suhu 10$50{ }^{\circ} \mathrm{C}$ dan merupakan jenis bakteri yang paling banyak dijumpai pada daerah tropis.

- Thermophill, yaitu bakteri yang tahan panas pada suhu 50-80 0C. bakteri ini banyak dijumpai pada tambang minyak yang berasal dari perut bumi.

Perombakan limbah dapat berjalan lebih cepat pada penggunaan bakteri thermophill. Suhu yang tinggi dapat memacu perombakan secara kimiawi, perombakan yang cepat akan dimanfaatkan oleh bakteri metahonogenik untuk menghasilkan gas methan, sehingga dapat produksi biogas. Peningkatan suhu sebesar 40 0C dapat menghasilkan 68,5 liter biogas (Mahajoeno, dkk, 2008).

Limbah cair mengandung karbohidrat, protein, lemak, dan mineral yang dibutuhkan oleh mikroba. Komposisi limbah perlu diperbaiki dengan penambahan nutrisi seperti untur $\mathrm{P}$ dan $\mathrm{N}$ yang diberkan dalam bentuk pupuk TSP dan urea. Jumlah kandungan bahan makanan dalam limbah harus dipertahankan agar bakteri tetap berkembang dengan baik. Jumlah lemak yang terdapat dalam limbah akan mempengaruhi aktivitas perombak limbah karbohidrat dan protein. Selain kontinuitas makanan juga kontak antara makanan dan bakteri perlu berlangsung dengan baik yang dapat dicapai dengan melakukan agitasi (pengadukan). agitasi juga berpengaruh terhadap produksi biogas. Pemberian agitasi berpengaruh lebih baik dibandingkan tanpa agitasi dalam peningkatan laju produksi gas. Dengan agitasi substrat akan menjadi homogen, inokulum kontak langsung dengan substrat dan merata, sehingga proses perombakan akan lebih efektif. Agitasi dimaksudkan agar kontak antara limbah cair PMKS dan bakteri perombak lebih baik dan menghindari padatan terbang atau mengendap. Agitasi pada $100 \mathrm{rpm}$ dapat meningkatkan produksi biogas.

Reaksi perombakan anaerobik tidak menginginkan kehadiran oksigen, karena oksigen akan menonaktifkan bakteri. Kehadiran oksigen pada limbah cair dapat berupa kontak limbah dengan udara. Kedalaman reaktor akan mempengaruhi reaksi perombakan. Semakin dalam reaktor akan semakin baik hasil perombakan.

Kehadiran bahan toksik juga menghambat proses produksi biogas. Kehadiran bahan toksik ini akan menghambat aktivitas mikroorganisme untuk melakukan perombakan. Maka untuk memperoleh produksi biogas yang baik, kehadiran bahan toksik harus dicegah.

Hasil produksi biogas juga ditentukan oleh faktor waktu fermentasi. Hal ini disebabkan untuk melakukan perombakan anaerob terdiri atas 4 (empat) tahapan. Untuk itu setiap proses membutuhkan waktu yang cukup. Pengaruh waktu fermentasi memberikan hasil yang berbeda pada produksi biogas. Semakin lama proses fermentasi, maka akan semakin tinggi produksi biogas. 
Ahmad (2003) menyatakan parameter kinetik merupakan dasar penting dalam desain bioreaktor terutama konstanta laju pertumbuhan mikroba maksimum dan menentukan waktu tinggal biomassa minimum. Parameter kinetik biodegradasi anerob limbah cair PMKS optimum diperoleh pada konstanta setengah jenuh (Ks) 1,06 g/L, laju pertumbuhan spesifik maksimum $(\mu \mathrm{m})$ 0,187 / hari, perolan biomassa (Y) 0,395 gVSS/gCOD, konstanta laju kematian mikroorganisme (Kd) 0,027 / hari, dan konstanta pemanfaatan substat maksimum (k) 0,474 / hari.

Potensi biogas yang dihasilkan dari $600-700 \mathrm{~kg}$ limbah cair PMKS dapat diproduksi sekitar $20 \mathrm{~m} 3$ biogas (Goenadi, 2006) dan setiap m3 gas methan dapat diubah menjadi energi sebesar $4.700-6.000$ kkal atau 20-24 MJ (Isroi, 2008). Sebuah PMKS dengan kapasitas 30 ton TBS/jam dapat menghasilkan tenaga biogas untuk energi setara 237 KwH (Naibaho, 1996).

Selain menghasilkan biogas, pengolahan limbah cair dengan proses digester anaerobik dapat dilakukan pada lahan yang sempit dan memberi keuntungan berupa penurunan jumlah padatan organik, jumlah mikroba pembusuk yang tidak diinginkan, serta kandungan racun dalam limbah. Di samping itu juga membantu peningkatan kualitas pupuk dari sludge yang dihasilkan, karena sludge yang dihasilkan berbeda dari sludge limbah cair PMKS biasa yang dilakukan melalui proses konvensional (Tobing, 1997). Kelebihan tersebut adalah :

- Penurunan kadar BOD bisa mencapai 80-90 \%.

- Baunya berkurang sehingga toidak disukai lalat.

- Berwarna coklat kehitam-hitaman.

- Kualitas sludge sebagai pupuk lebih baik, yaitu :

$>$ Memperbaiki struktur fisik tanah

$>$ Meningkatkan aerasi, peresapan, retensi, dan kelembaban

$>$ Meningkatkan perkembangbiakan dan perkembangan akar

$>$ Meningkatkan kandungan organik tanah, $\mathrm{pH}$, dan kapasitas tukar kation tanah, dan

$>$ Meningkatkan populasi mikroflora dan mikrofauna tanah maupun aktivitasnya.

Secara umum diagram alir proses pemanfaatan limbah cair kelapa sawit yang di ambil gas methane untuk menjadi biogas dan menghasilkan energi listrik digambarkan pada Gambar 1.

\section{Operasional Genset Berbahan Bakar Biogas}

Biogas mengandung beberapa komponen yaitu C02, sekitar $25 \%$ sampai $50 \%$ per volume, akibat yang ditimbulkan kandungan $\mathrm{CO} 2$ yaitu menurunkan nilai kalori, meningkatkan jumlah methane dan anti knock pada engine, menyebabkan korosi (kurangnya kandungan karbon acid)jika gas dalam keadaan basah, serta merusak alkali dalam baan bakar biogas ini. H2S, sekitar 0 sampai 0,5\%, akibat yang ditimbulkan kandungan H2S yaitu : mengakibatkan korosi pada peralatan dan system perpipaan (stress corrosion) oleh karena itu banyak produsen mesin 100 menetapkan batas maksimal $\mathrm{H} 2 \mathrm{~S}$ yang terkandung hanya $0,05 \%$ saja. NH3, sekitar 0-0,05\%, emisi NOx setelah pembakaran merusak kandungan bahan bakar biogas ini, dan meningkatkan sifat anti-knock pada engine. Uap air, sekitar 1-5\%, dapat menyebabkan korosi, risiko pembekuan, pada peralatan, instrument, plant dan system perpipaan.

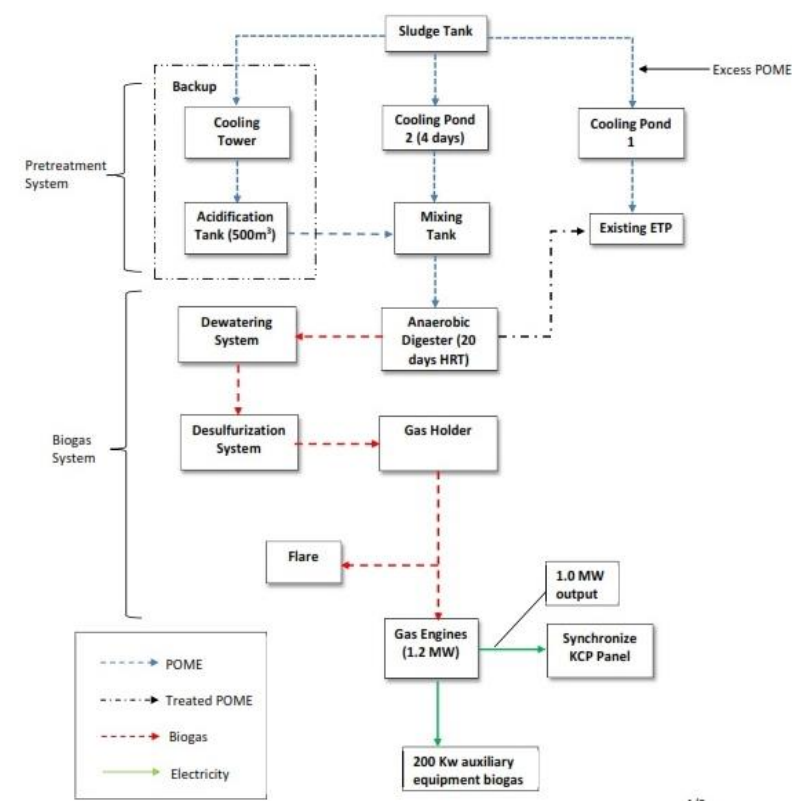

Gambar 1. Contoh Salah Satu Diagram alir Unit Pengolahan biogas

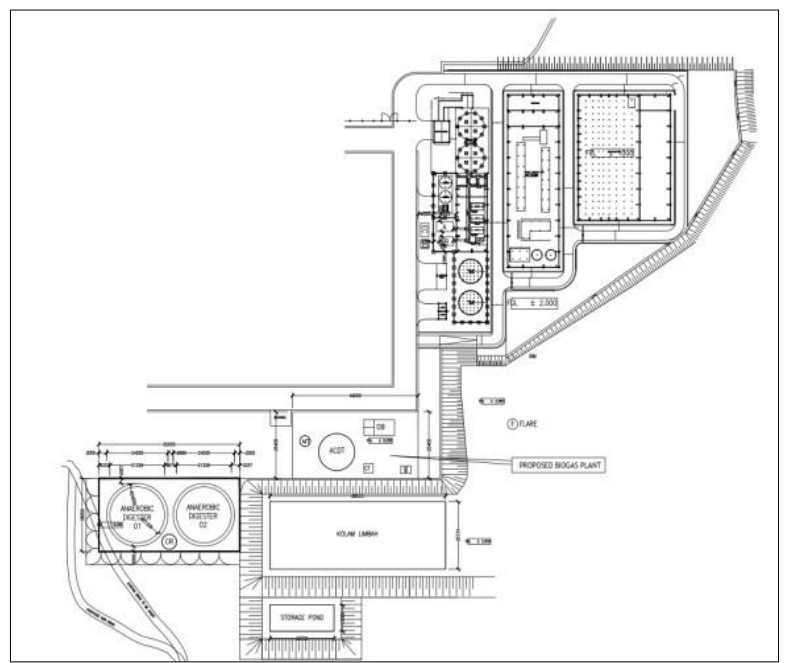

Gambar 2. Contoh Layout Unit Pengolahan Biogas PT. Laguna Mandiri.

Debu / Dust, sekitar $>5 \mu \mathrm{m}$, mengakibatkan terhalangnya nozzle, dan kandungan biogas. N2, sekitar 0-5\%, akibat yang ditimbulkan yaitu mengurangi kandungan nilai kalori, dan meningkatkan anti-knock pada engine. Siloxanes, sekitar 0-5mg m-3, mengakibatkan terjadinya abrasive dan kerusakan pada mesin.

Perubahan biogas menjadi energi listrik dilakukan dengan memasukkan gas dalam tabung penampungan kemudian masuk ke conversion kit yang berfungsi menurunkan tekanan gas dari tabung 
Alkusma, Y.M., Hermawan, dan Hadiyanto. (2016). Pengembangan Potensi Energi Alternatif dengan Pemanfaatan Limbah Cair Kelapa Sawit sebagai Sumber Energi Baru Terbarukan di Kabupaten Kotawaringin Timur. Jurnal Ilmu Lingkungan,14(2),96-102, doi:10.14710/jil.14.2.96-102

sesuai dengan tekanan operasional mesin dan mengatur debit gas yang bercampur dengan udara di dalam mixer, dari mixer bahan bakar bersama dengan udara masuk kedalam mesin dan terjadilah pembakaran yang akan menghasilkan daya untuk menggerakkan generator yang menghasilkan energi listrik. Karakteristik pembakaran yang terjadi pada mesin diesel berbeda dengan pembakaran pada mesin bensin.

$>$ Karakteristik pembakaran biogas di dalam mesin diesel

Bahan bakar biogas membutuhkan rasio kompresi yang tinggi untuk proses pembakaran sebab biogas mempunyai titik nyala yang tinggi $645^{\circ} \mathrm{C}-$ $750^{\circ} \mathrm{C}$ dibandingkan titik nyala solar $220^{\circ} \mathrm{C}$, maka mesin diesel umumnya digunakan secara dualfuel dengan rasio kompresi sekitar 15 - 18. Proses pembakaran pada mesin dualfuel, bahan bakar biogas dan udara masuk ke ruang bakar pada saat langkah hisap dan kemudian dikompresikan di dalam silinder seperti halnya udara dalam mesin diesel biasa. Bahan bakar solar dimasukkan lewat nosel pada saat mendekati akhir langkah kompresi, dekat titik mati atas (TMA) sehingga terjadi pembakaran.

Temperatur awal kompresi tidak boleh lebih dari $80{ }^{\circ} \mathrm{C}$ karena akan menyebabkan terjadinya knocking dan peristiwa knocking yang terjadi pada mesin dualfuel hampir sama dengan yang terjadi pada mesin bensin, yaitu terjadinya pembakaran yang lebih awal akibat tekanan yang tinggi dari mesin diesel. Hal ini disebabkan karena bahan bakar biogas masuk bersama-sama dengan udara ke ruang bakar, sehingga yang dikompresikan tidak hanya udara tapi juga biogas

$>$ Karakteristik pembakaran biogas di dalam mesin bensin

Mesin bensin dengan rasio kompresi yang hanya berkisar antara 6 - 9,5 tidak cukup untuk melakukan pembakaran biogas karena titik nyala biogas yang tinggi $645^{\circ} \mathrm{C}-750{ }^{\circ} \mathrm{C}$, untuk itu dilakukan penambahan rasio kompresi mesin menjadi $10-12$. Proses pembakaran biogas sama seperti pada mesin bensin normal, yaitu biogas dan udara masuk ke ruang bakar dan pada akhir langkah kompresi terjadi pembakaran, pembakaran ini terjadi karena bantuan loncatan bunga api dari busi.

\section{Perkebunan di Kabupaten Kotawaringin Timur}

Kabupaten Kotawaringin Timur merupakan salah satu dari 13 kabupaten/kota yang ada di Propinsi Kalimantan Tengah. Secara geografis berkedudukan pada $112^{\circ} 7^{\prime} 29^{\prime \prime}-113^{\circ} 14^{\prime} 22^{\prime \prime}$ Bujur Timur dan $1^{\circ} 11^{\prime} 504^{\prime \prime}-3^{\circ} 18^{\prime} 51^{\prime \prime}$ Lintang Selatan, dengan luas wilayah $16.496 \mathrm{Km}$

Potensi sektor tanaman perkebunan di Kabupaten Kotawaringin Timur meliputi karet, kelapa dalam, kopi, lada dan kelapa sawit. Untuk tanaman perkebunan rakyat, karet dan kelapa dalam merupakan komoditas yang memiliki luas terbesar. Kelapa dalam terkonsentrasi di wilayah pesisir Kabupaten Kotawaringin Timur dengan Kecamatan Mentaya Hilir Selatan mempunyai luas terbesar diikuti Kecamatan Pulau Hanaut. Untuk perkebunan karet terutama berkembang di wilayah tengah sampai utara Kabupaten Kotawaringin Timur dengan luas terbesar di Kecamatan Mentaya Hulu. Untuk perkebunan kelapa sawit diusahakan oleh perkebunan besar swasta dengan pola inti atau plasma dengan kelompok tani atau Koperasi Unit Desa (KUD). Di Kabupaten Kotawaringin Timur Terdapat 60 PBS kelapa sawit dengan luas lahan pencadangan total mencapai $681.415,16 \mathrm{Ha}$ dan luas lahan penanaman total mencapai 461.237,3 $\mathrm{Ha}$, yang terdiri atas inti seluas $404.360,7 \mathrm{Ha}$ dan plasma seluas 56.876,6 Ha. Dari 60 PBS yang telah beroperasi tersebut, terdapat 25 PBS yang telah memiliki pabrik pengolahan kelapa sawit, dimana 10 diantaranya berada di lintas kabupaten dengan total kapasitas produksi mencapai 1.490 ton TBS/jam.

Tabel 1. Perusahaan PBS yang Memiliki Pabrik Pengolahan Kelapa Sawit di Kabuopaten Kotawaringin Timur per Deember 2014

\begin{tabular}{|c|c|c|}
\hline No & Nama Perusahaan & $\begin{array}{l}\text { Kapasitas Pabrik PKS } \\
\text { (ton TBS/jam) }\end{array}$ \\
\hline 1. & PT. Karya Makmur Bahagia & 75 \\
\hline 2. & PT. Karya Makmur Bahagia (II) & 45 \\
\hline 3. & PT. Katingan Indah Utama & 90 \\
\hline 4. & PT. Uni Primacom & 20 \\
\hline 5. & PT. Suka Jadi Sawit Mekar (I) & 90 \\
\hline 6. & PT. Sukajadi Sawit Mekar (II) & 45 \\
\hline 7. & PT. Tunas Agro Subur Kencana & 120 \\
\hline 8. & PT. Windu Nabatindo Lestari & 90 \\
\hline 9. & PT. Swadaya Sapta Putra & 45 \\
\hline 10. & PT. Sapta Karya Damai & 30 \\
\hline 11. & PT. Bangkit Giat Usaha Mandiri & 45 \\
\hline 12. & PT. Maju Aneka Sawit & 45 \\
\hline 13. & PT. Sarana Prima Multi Niaga & 45 \\
\hline 14. & PT. Agro Bukit & 90 \\
\hline 15. & PT. Bumi Sawit Kencana & 45 \\
\hline 16. & PT. Surya Inti Sawit Kahuripan & 60 \\
\hline 17. & PT. Mentaya Sawit Mas & 45 \\
\hline 18. & PT. Hutan Sawit Lestari & 90 \\
\hline 19. & PT. Unggul Lestari & 45 \\
\hline 20. & PT. Windu Nabatindo Abadi & 60 \\
\hline 21. & PT. Adhyaksa Dharmasatya & 30 \\
\hline 22. & PT. Agro Wana Lestari & 90 \\
\hline 23. & PT. Karunia Kencana Permaisejati & 45 \\
\hline 24. & PT. Mulia Agro Permai & 60 \\
\hline \multirow[t]{2}{*}{25} & PT. Intiga Prabhakara Kahuripan & 45 \\
\hline & TOTAL KOTIM & 1.490 \\
\hline 1. & PT. Agro Indomas (I) ${ }^{*}$ ) & 90 \\
\hline 2. & PT. Agro Indomas ( II )*) & 90 \\
\hline 3. & PT. Kridatama Lancar *) & 60 \\
\hline 4. & PT. Bisma Dharma Kencana *) & 30 \\
\hline 5. & PT. Mustika Sembuluh (I) *) & 60 \\
\hline 6. & PT. Mustika Sembuluh (II) *) & 45 \\
\hline 7. & PT. Teguh Sempurna*) & 30 \\
\hline 8. & PT. Bumi Hutani Lestari *) & 60 \\
\hline 9. & $\begin{array}{l}\text { PT. Tapian Nadenggan (Unit } \\
\text { Semilar) *) }\end{array}$ & 80 \\
\hline \multirow[t]{2}{*}{10.} & $\begin{array}{l}\text { PT. Agrokarya Primalestari (Unit } \\
\text { Kuayan) }{ }^{*} \text { ) }\end{array}$ & 80 \\
\hline & TOTAL LINTAS KABUPATEN & 625 \\
\hline
\end{tabular}

*) : Lintas Kabupaten tahun 2014

Sumber : Dinas Perkebunan Provinsi Kalimantan Tengah, 
Sebanyak 25 perusahaan yang telah memiliki pabrik pengolahan kelapa sawit dengan kapasitas olah Tandan Buash Segar mencapai 1.490 ton TBS/jam dan 10 pabrik pengolahan kelapa sawit berada di lintas kabupaten Kotawaringin Timur dengan total kapasitas olah pabrik sebesar 625 ton TBS /jam, dengan asumsi material balance selama proses produksi tandan buah segar kelapa sawit secara umum dimana limbah cair yang dihasilkan adalah sebesar $60 \%$ dari total proses produksi. Dengan demikian jumlah kapasitas pabrik total di Kabupaten Kotawaringin Timur sebesar 2.115 ton TBS/jam, maka limbah cair yang dihasilkan adalah sebesar 1.269 ton limbah cair/jam dihasilkan selam proses produksi berlangusng. Dengan potensi limbah cair kelapa sawit yang bisa menghasilkan biogas sangat besar. Dimana beradasarkan asumsi bahwa setiap 600 - $700 \mathrm{~kg}$ limbah cair yang dihasilkan dapat di produksi sekitar $20 \mathrm{~m}^{3}$ biogas (Goenadi, 2006) maka potensi biogas yang ada di Kabupaten Kotawaringin Timur adalah sebesar $42.300 \mathrm{~m}^{3}$ biogas. Dengan besarnya potensi biogas yang dihasilkan tersebut pemerintah kabupaten Kotawaringin Timur berpeluang besar untuk melakukan pengembangan penggunaan energi baru terbarukan yang berasal dari Limbah Cair Kelapa Sawit. Yang pada akhirnya akan meningkatkan rasio eletrifikasi yang saat ini hanya sebesar $60 \%$.

\section{Penutup}

Dengan meningkatnya kebutuhan energi di Kabupaten Kotawaringin Timur, dengan berkembang pesatnya potensi ekonomi dari sektor pertanian subsektor perkebunan, maka penggunaan energi baru terbarukan sangat penting untuk dikembangkan. Mengingat kondisi pembangunan energi listrik yang belum merata, maka kebutuhan pasokan energi listrik bagi daerah terpencil dan tersebar di Kabupaten Kotawaringin Timur, hendaknya pemerintah Daerah mendorong pihak perusahaan besar swasta yang bergerak di bidang perkebunan kelapa sawit untuk bisa memanfaatkan energi yang berasal dari limbah cair kelapa sawit yang melimah keberadaanya.

Dengan Total kapasitas pabrik di Kabupaten Kotawaringin Timur sebesar 2.115 ton TBS/jam, maka limbah cair yang bisa di manfaatkan adalah sebsar 1.269 ton limbah cari/jam dan mampu menghasilkan biogas sebesar $1.269 .000 \mathrm{~m}^{3}$.

Diperlukan adanya perhitungan dan kajian yang lebih mendalam berapa besar potensi limbah cair kelapa sawit yang dapat di manfaatkan untuk memenuhi kebutuhan energi di Kabupaten Kotawaringin Timur.

\section{DAFTAR PUSTAKA}

Anonim. (2015) Dokumen Addendum AMDAL Pemanfaatan Biogas PT. Laguna Mandiri Kab. Kotabaru, Provinsi Kalimantan Selatan

Anonim. (2012). Materi Teknik RTRW Kabupaten Kotawaringin Timur Tahun 2012-2032. Bappeda Kab. Kotim
Brojonegoro, B., \& Permadi, B. (1992). "AHP" Pusat Antar Universitas, Studi Ekonomi. Jakarta : UI

Budiati, Lilin. (2014). Good Governance dalam Pengelolaan Lingkungan Hidup. Ghalia Indonesia. Bandung

Danim, S. (2002).Menjadi Peneliti Kualitatif. Pustaka Setia. Bandung.

Ginting, Perdana (2007). Sistem Pengelolaan Lingkungan dan Limbah Industri. CV. Yrama Widya. Bandung.

Hariyadi. 2009. Dampak Ekologi Pengembangan Kelapa Sawit untuk Bioenergi.

http:/energi.infogue.com/dampak_ekologi_pengembangan_ kelapa_sawit_untuk_bioenergi. (17 Maret 2009).

Isroi. 2008. Energi Terbarukan dari Limbah Pabrik Kelapa Sawit. isroi.wordpress.com/2008/02/2005energi_dari_limbah_sa wit/-70-k. (17 Maret 2009).

Keputusan Menteri KLH Nomor KEP 51/MEN KLH/10/1995 tentang Baku Mutu Limbah Cair bagi Kegiatan Industri.

Mahajoeno, Edwi, Lay, Bibiana Widiati, Sutjahjo, Suryo Hadi, dan Siswanto. 2008. Potensi Limbah Cair Pabrik Minyak Kelapa Sawit untuk Produksi Biogas. Jurnal Bioversitas Volume 9 No. 1.

Mutu'ali, L. ((2012). Daya Dukung Lingkungan untuk Perencanaan Pengembangan Wilayah. Badan Penerbit Fakultas Geografi Universitas Gadjah Mada. Yogyakarta.

Naibaho, Ponten M. 1996. Teknologi Pengolahan Kelapa Sawit, Medan : Pusat Penelitian Kelapa Sawit.

Naibaho, Ponten M. 1999. Aplikasi Biologi dalam Pembangunan Industri Berwawasan Lingkungan, Jurnal Visi 7.

Nazir, Moh. 2005. Metode Penelitian. Penerbit Ghalia Indonesia. Bogor

Sastrosayono, S., 2003. Budidaya Kelapa Sawit. Agromedia Pustaka, Jakarta.

Setyamidjaja, D. 2006. Budidaya Kelapa Sawit. Kanisius. Yogyakarta. 62 Hal.

Soerjani, Muhamad, Yowono, Arief, dan Fardiaz, Dedi. 2007. Lingkungan : Pendidikan, Pengelolaan Lingkungan, dan Keberlanjutan Pembangunan, Jakarta; Yayasan Institut Pendidikan dan Pelatihan Lingkungan Jakarta

Sunarko, 2008. Petunjuk Praktis Budidaya dan Pengolahan Kelapa Sawit. Agromedia Pustaka, Jakarta

Wahyuni, Sri. (2013). Panduan Praktis Biogas. Penebar Swadaya. Jakarta 